\title{
Humidity-dependent phase state of SOA particles from biogenic and anthropogenic precursors
}

\author{
E. Saukko ${ }^{1}$, A. T. Lambe ${ }^{2,3}$, P. Massoli ${ }^{3}$, T. Koop ${ }^{4}$, J. P. Wright ${ }^{2}$, D. R. Croasdale ${ }^{2}$, D. A. Pedernera ${ }^{4, *}$, T. B. Onasch ${ }^{2,3}$ \\ A. Laaksonen ${ }^{5,6}$, P. Davidovits ${ }^{2}$, D. R. Worsnop ${ }^{3,7}$, and A. Virtanen ${ }^{1,6}$ \\ ${ }^{1}$ Department of Physics, Tampere University of Technology, Tampere, Finland \\ ${ }^{2}$ Chemistry Department, Boston College, Chestnut Hill, MA, USA \\ ${ }^{3}$ Aerodyne Research Inc., Billerica, MA, USA \\ ${ }^{4}$ Faculty of Chemistry, Bielefeld University, Bielefeld, Germany \\ ${ }^{5}$ Finnish Meteorological Institute, Helsinki, Finland \\ ${ }^{6}$ Department of Applied Physics, University of Eastern Finland, Kuopio, Finland \\ ${ }^{7}$ Division of Atmospheric Sciences, Department of Physics, University of Helsinki, Helsinki, Finland \\ *now at: Faculty of Mathematics, Astronomy and Physics, National University of Córdoba, Córdoba, Argentina
}

Correspondence to: A. Virtanen (annele.virtanen@uef.fi)

Received: 22 December 2011 - Published in Atmos. Chem. Phys. Discuss.: 8 February 2012

Revised: 16 July 2012 - Accepted: 7 August 2012 - Published: 17 August 2012

\begin{abstract}
The physical phase state (solid, semi-solid, or liquid) of secondary organic aerosol (SOA) particles has important implications for a number of atmospheric processes. We report the phase state of SOA particles spanning a wide range of oxygen to carbon ratios $(\mathrm{O} / \mathrm{C})$, used here as a surrogate for SOA oxidation level, produced in a flow tube reactor by photo-oxidation of various atmospherically relevant surrogate anthropogenic and biogenic volatile organic compounds (VOCs). The phase state of laboratory-generated SOA was determined by the particle bounce behavior after inertial impaction on a polished steel substrate. The measured bounce fraction was evaluated as a function of relative humidity and SOA oxidation level $(\mathrm{O} / \mathrm{C})$ measured by an Aerodyne high resolution time of flight aerosol mass spectrometer (HR-ToF AMS).

The main findings of the study are: (1) biogenic and anthropogenic SOA particles are found to be amorphous solid or semi-solid based on the measured bounced fraction (BF), which was typically higher than 0.6 on a 0 to 1 scale. A decrease in the BF is observed for most systems after the SOA is exposed to relative humidity of at least $80 \% \mathrm{RH}$, corresponding to a RH at impaction of $55 \%$. (2) Long-chain alkanes have a low BF (indicating a "liquid-like", less viscous phase) particles at low oxidation levels $(\mathrm{BF}<0.2 \pm 0.05$ for $\mathrm{O} / \mathrm{C}=0.1$ ). However, $\mathrm{BF}$ increases substantially upon in-
\end{abstract}

creasing oxidation. (3) Increasing the concentration of sulphuric acid $\left(\mathrm{H}_{2} \mathrm{SO}_{4}\right)$ in solid SOA particles (here tested for longifolene SOA) causes a decrease in BF levels. (4) In the majority of cases the bounce behavior of the various SOA systems did not show correlation with the particle $\mathrm{O} / \mathrm{C}$. Rather, the molar mass of the gas-phase VOC precursor showed a positive correlation with the resistance to the $\mathrm{RH}$-induced phase change of the formed SOA particles.

\section{Introduction}

The direct and indirect effects of aerosol particles on the Earth's radiative budget remain the largest source of uncertainty in climate change modeling (IPCC, 2007, ch. 2). In many locations, organic matter (OM) forms up to $90 \%$ of observed submicron aerosol particulate mass, and secondary organic aerosol (SOA) represents up to half of the organic fine fraction (Jimenez et al., 2009; Hallquist et al., 2009).

SOA particles are formed from oxidation of gas-phase organic precursors. The volatility of the VOCs decreases as their functionalization and thus binding ability increases (Donahue et al., 2012), causing their vapor pressure to decrease until the gaseous compounds either condense on existing particles or nucleate to form new particles. The SOA

Published by Copernicus Publications on behalf of the European Geosciences Union. 
formation process under natural conditions is complicated and it involves a multitude of gaseous precursors and a greater number of particle product compounds. Up to now, the modeling of formation and aging of SOA has been mostly based on gas-particle equilibrium partitioning of volatile and semivolatile species (Pankow, 1994; Kanakidou et al., 2005). This implies fast enough condensed phase diffusion rates to keep the condensed phase in equilibrium with the gas phase as the particles' size increases and the concentration of VOCs decreases.

However, several recent studies show that at least under some conditions natural and laboratory-produced SOA particles have an amorphous solid state (Virtanen et al., 2010; Cappa and Wilson, 2011; Vaden et al., 2011). The solid amorphous state of SOA particles has important implications for a number of atmospheric processes. First, a solid phase implies surface-confined chemistry and kinetic limitations to achieve equilibrium partitioning between the gas phase and the particle phase. More importantly, chemical reactions are impeded in viscous aerosol particles (Zahardis and Petrucci, 2007; Shiraiwa et al., 2011; Pfrang et al., 2011; Ziemann, 2010), because mass transport (diffusion) of reactants within the aerosol particle bulk may become the rate limiting step. Shiraiwa et al. (2011) showed that these kinetic limitations can increase the chemical lifetime of (semi-)solid particles by more than an order of magnitude. The water uptake of highly viscous SOA particles may also be diminished or even fully inhibited, in particular at low temperatures, with implications for the particles' size and scattering properties and their direct effect on climate (Zobrist et al., 2008; Murray, 2008; Mikhailov et al., 2009; Koop et al., 2011). The particles in a glassy state can also catalyse ice formation in cirrus conditions and thus have significant implications on the water-particle interactions at upper atmosphere (Murray et al., 2010).

All recent studies reporting a solid phase of SOA particles (Virtanen et al., 2010; Cappa and Wilson, 2011; Vaden et al., 2011) have focused on studying the properties of laboratory or ambient SOA in dry conditions $(\mathrm{RH}<40 \%)$. In order to assess how general is the occurrence of the amorphous solid state of the SOA, and how other factors might affect particle phase state, we report a systematic characterization of the phase of laboratory SOA as a function of $\mathrm{O} / \mathrm{C}$ and relative humidity $(\mathrm{RH})$. The SOA particles were generated from the ${ }^{*} \mathrm{OH}$ oxidation of several atmospherically relevant anthropogenic and biogenic precursors. A low pressure impactor (LPI) equipped with an optical counting arrangement provided a measurement of the phase of the SOA particles, based on the idea that "liquid-like" particles are collected on the impactor stage with minimal bounce, whereas detection of particles downstream of the impactor indicates that particles are bouncing off of the impactor stage and suggests the presence of an amorphous semi-solid or solid state. Other chemical and microphysical properties of the SOA particles were characterized with a Scanning Mobility Particle
Sizer (SMPS) (TSI), Cloud Condensation Nuclei Counter (CCNC), and High-Resolution Time-of-Flight Aerosol Mass Spectrometer (HR-ToF-AMS).

\section{Experimental}

\subsection{SOA particle generation}

SOA particles were generated with a Potential Aerosol Mass (PAM) flow tube reactor, which is a horizontal 151 glass cylindrical chamber $46 \mathrm{~cm}$ long $\times 22 \mathrm{~cm}$ ID. The details of the reactor used are described in Lambe et al. (2011a). The reactor is capable of simulating atmospheric oxidation timescales of days to weeks with actual residence times of minutes. Previous studies have shown that the PAM reactor can produce SOA at a level of oxidation that is atmospherically-relevant (Massoli et al., 2010; Lambe et al., 2011 b, 2012) but unattainable by conventional smog chamber techniques that are limited to $\sim 1$ day of equivalent atmospheric oxidation (e.g. $\mathrm{Ng}$ et al., 2010).

SOA was generated via gas-phase oxidation of precursors (shown in Fig. 1), followed by homogeneous nucleation. Volatile organic compound (VOC) precursors used in this study were isoprene and $\alpha$-pinene. VOC precursors were prepared in compressed gas cylinders or in glass bubblers and introduced into the PAM reactor with $\mathrm{N}_{2}$ carrier gas at controlled rates using a mass-flow controller. Intermediate volatility organic compound (IVOC) precursors used in this study were $n$-heptadecane, longifolene, and naphthalene. With the exception of naphthalene, IVOCs were introduced into the carrier gas flow using a permeation tube placed in a temperature-controlled oven. Naphthalene vapor was introduced by flowing $\mathrm{N}_{2}$ over solid naphthalene placed in a Teflon tube.

Organic species were transported through the PAM reactor by a carrier gas consisting of $8.5 \mathrm{lpm} \mathrm{N}_{2}$ and $0.5 \mathrm{lpm} \mathrm{O}_{2}$. The average species residence time in the PAM reactor was typically 100 s. Four mercury lamps (BHK Inc.) with peak emission intensity at $\lambda=254 \mathrm{~nm}$ were mounted in teflon-coated quartz cylindrical sleeves inside the chamber, and were continually purged with $\mathrm{N}_{2}$.

$\mathrm{OH}$ radicals $\left({ }^{*} \mathrm{OH}\right)$ were produced via the reaction $\mathrm{O}_{3}+$ $\mathrm{h} v \rightarrow \mathrm{O}_{2}+\mathrm{O}\left({ }^{1} \mathrm{D}\right)$ followed by the reaction $\mathrm{O}\left({ }^{1} \mathrm{D}\right)+\mathrm{H}_{2} \mathrm{O}$ $\rightarrow 2^{*} \mathrm{OH} . \mathrm{O}_{3}$ was generated by irradiating $\mathrm{O}_{2}$ with a mercury lamp $(\lambda=185 \mathrm{~nm})$ outside the PAM reactor. Oxygen $\left(\mathrm{O}\left({ }^{1} \mathrm{D}\right)\right)$ radicals were produced by UV photolysis of $\mathrm{O}_{3}$ inside the PAM reactor. The radical $\mathrm{O}\left({ }^{1} \mathrm{D}\right)$ then reacted with water vapor (introduced using a heated Nafion membrane humidifier; Perma Pure LLC) to produce ${ }^{*} \mathrm{OH}$ inside the PAM reactor. Most experiments were conducted at RH values ranging from $30 \%$ to $40 \%$, depending on the temperature in the PAM reactor $\left(22-32^{\circ} \mathrm{C}\right)$ at different UV lamp settings. At a given measured relative humidity, this parameter remained constant to within $\pm 5 \%$. 


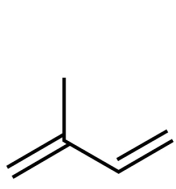

Isoprene

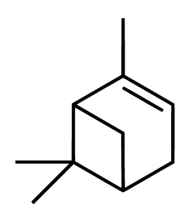

$\alpha$-pinene

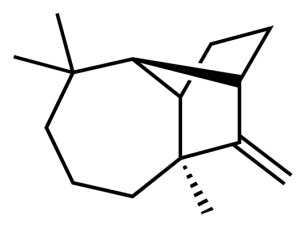

Longifolene
Naphthalene

n-heptadecane

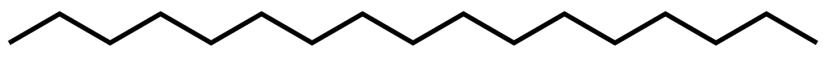

Fig. 1. Molecular structures of the VOC and IVOC gaseous precursors used to generate SOA for the experiment: biogenic precursors are in the top row, anthropogenic model precursors are on the bottom.

The ${ }^{*} \mathrm{OH}$ exposure, which is the product of the ${ }^{*} \mathrm{OH}$ concentration and the average residence time in the PAM reactor, was varied by changing the UV light intensity through stepping the voltage applied to the lamps between 0 and $110 \mathrm{~V}$. The ${ }^{*} \mathrm{OH}$ exposure was determined indirectly by measuring the decay of $\mathrm{SO}_{2}$ due to reaction with ${ }^{*} \mathrm{OH}$ in the PAM reactor. $\mathrm{SO}_{2}$ calibration measurements were conducted as a function of UV lamp intensity and $\mathrm{O}_{3}$ concentration (Lambe et al., 2011a). Typical ${ }^{*} \mathrm{OH}$ exposures ranged from $2.7 \times 10^{11}$ to $2.2 \times 10^{12} \mathrm{molec} \mathrm{cm}^{-3} \mathrm{~s}$. These values are equivalent to 2 to 17 days of atmospheric oxidation assuming an average atmospheric ${ }^{*} \mathrm{OH}$ concentration of $1.5 \times 10^{6} \mathrm{molec} \mathrm{cm}^{-3}$ (Mao et al., 2009). However, we note that this equivalent "atmospheric age" may be a factor of 2 or more uncertain depending on the assumed ambient ${ }^{*} \mathrm{OH}$ concentration.

While ${ }^{*} \mathrm{OH}$ concentrations in these experiments (approximately $2.7 \times 10^{9}$ to $2.2 \times 10^{10}$ molec $\mathrm{cm}^{-3}$ ) are higher than ambient ${ }^{*} \mathrm{OH}$ concentrations, the integrated ${ }^{*} \mathrm{OH}$ exposures are similar. Previous work suggests that, to first order, extrapolation of flow tube reactor conditions (high $\left[{ }^{*} \mathrm{OH}\right]$, short exposure times) to atmospheric conditions (low $\left[{ }^{*} \mathrm{OH}\right]$, long exposure times) is reasonable (Renbaum and Smith, 2011). Even though both $\mathrm{O}_{3}$ and ${ }^{*} \mathrm{OH}$ can oxidize organic species, ${ }^{*} \mathrm{OH}$ was the principal oxidant in all experiments except for selected studies, where experiments with $\mathrm{O}_{3}$ as the oxidizing agent were conducted by turning the lamps off. Prior to each experiment, the PAM reactor was conditioned with * $\mathrm{OH}$ radicals until a particle background less than 10 particles $\mathrm{cm}^{-3}$ was attained.

In some experiments, internally mixed SOA - sulfuric acid particles were produced by introducing $\mathrm{SO}_{2}$ along with the $\mathrm{SOA}$ precursor, which is oxidized by $* \mathrm{OH}$ to produce sulfuric acid $\left(\mathrm{H}_{2} \mathrm{SO}_{4}\right)$ in the presence of water vapor (Seinfeld and Pandis, 1998, ch. 6.13).

\subsection{Particles phase state measurement}

The device used in this study to measure the particle bounce is described in detail in Saukko et al. (2012). The system consists of a low pressure impactor and a polished steel substrate. Size-selected aerosol is guided through a sampling cell (see Fig. 2) at low pressure until the system is stabilized, after which the cell is closed and re-pressurised to bring the sample to the working conditions of a TSI Ultrafine Water Condensation Particle Counter (WCPC), i.e. ambient pressure. This particle number concentration is compared to the particle concentration measured upstream of the impactor. The bounced fraction is the ratio of the particle concentrations measured after and before the impactor, divided by a similar ratio (baseline sample) obtained without the impaction substrate. The method is conceptually similar to that used by Virtanen et al. (2010), but the optical detection of particles employed here removes the effect of charge transfer processes. Accurate scales relating the bounced fraction to mechanical or other properties of the particles have not, however, been established yet.

The RH of the sampled aerosol is adjusted between 28 and $91 \%$ RH by a Nafion humidifier (PermaPure). The Nafion capillaries are fed with a mixture of $\sim 100 \% \mathrm{RH}$ air from water-fed micro-pore humidifier (Enerfuel) and $<5 \% \mathrm{RH}$ pressurized air. The aerosol sample flows around the Nafion capillaries and the water vapor is transferred from the humidifying flow. The output humidity is adjusted with the ratio of the saturated and $<5 \% \mathrm{RH}$ airflows.

The RH history of the sampled aerosol is slightly more complicated than the simple humidification by the Nafion tube: as the aerosol enters the impactor, the upstage pressure is $690 \mathrm{kPa}$, which is approximately $70 \%$ of the ambient pressure. Thus, the water vapour is diluted by expansion and the range of sample RH values upstream of the impactor ( $28 \%$ to $91 \% \mathrm{RH}$ ) corresponds to a range of reduced $\mathrm{RH}$ of $20 \%$ to $64 \%$ RH inside the impactor. The validity of this RH scaling is shown in Saukko et al. (2012), where deliquescence and efflorescence relative humidities for ammonium sulfate are obtained to within $3 \% \mathrm{RH}$ of literature values. This indicates that the temperature changes in impactor jet do not affect the relevant humidity inside the impactor. The equilibration time for the aerosol at this reduced RH is $0.9 \mathrm{~s}$ (Saukko et al., 2012), which at room temperature is sufficient for $100 \mathrm{~nm}$ particles to equilibrate with the gas phase humidity even if a semi-solid or solid state was obtained prior to entering the impactor (Koop et al., 2011; Zobrist et al., 2011). The particle sizes used in the experiments were between 105 and $160 \mathrm{~nm}$ in mobility diameter, and 130 to $230 \mathrm{~nm}$ in aerodynamic diameter. 


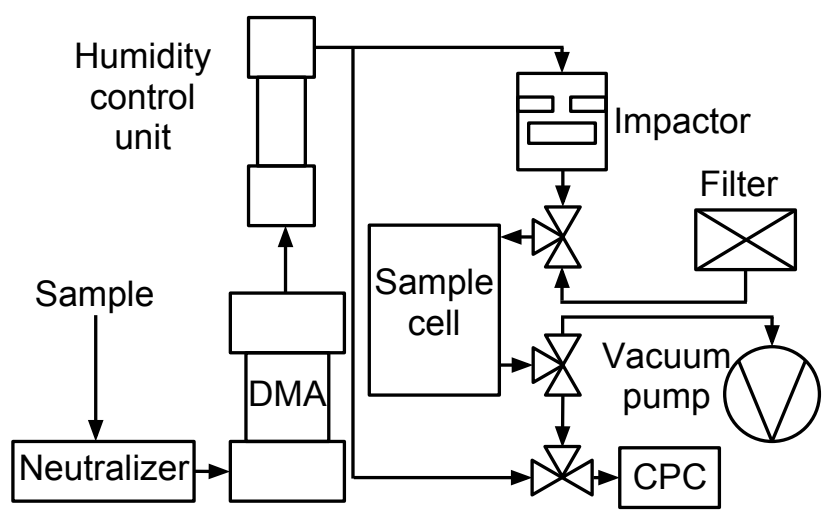

Fig. 2. The measurement system for the particle phase measurement.

\subsection{SOA CCNC measurements}

The CCN activity of SOA particles was measured with a continuous flow CCN counter (CCNC) (Roberts and Nenes, 2005; Lance et al., 2006). The PAM-generated SOA was size-selected using a TSI 3080 DMA prior to CCN number concentration measurements with the CCNC and total particle number concentration measurements with a CPC (TSI 3022A). CCN activation curves were generated by holding the particle size constant while systematically varying the CCNC column temperature gradient to obtain controlled water vapor supersaturation between $0.1-1.5 \%$ or until $100 \%$ activation was reached, as described in Massoli et al. (2010) and Lambe et al. (2011a). The CCN activity, $\kappa$, was calculated using the approach by Petters and Kreidenweis (2007). Selected dry mobility diameters ranged from 55 to $85 \mathrm{~nm}$ for SOA.

\subsection{SOA elemental ratios}

The chemical composition of the laboratory generated SOA were obtained with an Aerodyne HR-ToFAMS (DeCarlo et al., 2006). Elemental analysis yielding oxygen-to-carbon $(\mathrm{O} / \mathrm{C})$ and hydrogen-to-carbon $(\mathrm{H} / \mathrm{C})$ ratios was performed on the high-resolution measurements using ToF-AMS analysis software (Squirrel and Pika: http://cires.colorado.edu/jimenez-group/ ToFAMSResources/ToFSoftware/index.html).

The absolute accuracies for $\mathrm{O} / \mathrm{C}$ and $\mathrm{H} / \mathrm{C}$, determined by comparison to laboratory standards (Aiken et al., 2007, 2008), are $31 \%$ and $10 \%$, respectively. These values represent upper limits to the uncertainty of measurements for complex OA (Chhabra et al., 2010). The variability of the measurements can be captured by the precision error (standard deviation) which for these laboratory conditions was less than $\pm 5 \%$. Table 1 shows the range of $\mathrm{O} / \mathrm{C}$ ratio, $\mathrm{H} / \mathrm{C}$ ratio and $\mathrm{CCN} \kappa$ values for the SOA particles that were stud-

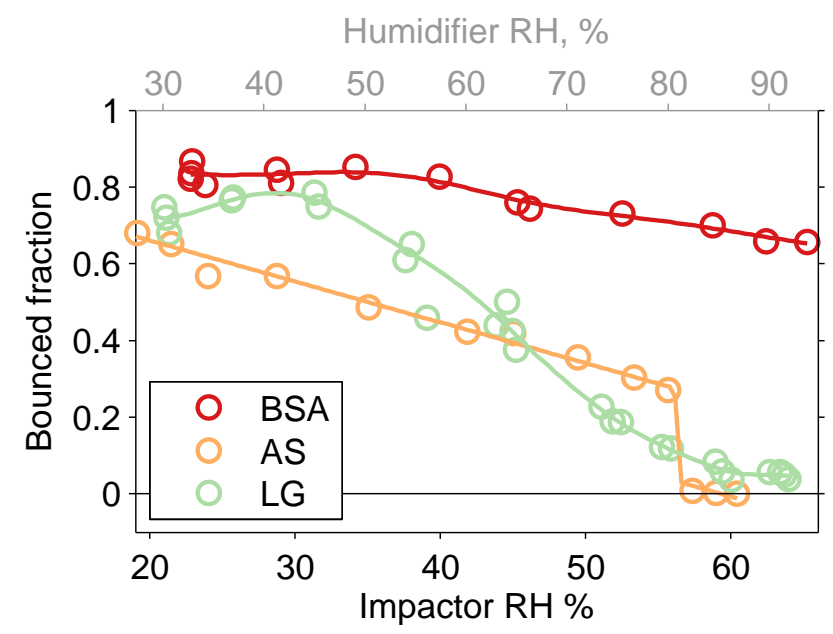

Fig. 3. Reference bounce characteristics of ammonium sulfate (AS) (crystalline), bovine albumin serum (BSA) (amorphous) and levoglucosan (LG) (amorphous).

ied in this work, along with the corresponding ${ }^{*} \mathrm{OH}$ exposures in the PAM reactor.

\section{Results}

Figure 3 shows the BF measured with the LPI for ammonium sulfate (AS), bovine albumine serum (BSA) and levoglucosan (LG) particles (Saukko et al., 2012). As can be seen in the figure, the bounce measured for AS particles decreases well below the deliquescence point. In Saukko et al. (2012) this is explained by the formation of water layer on the solid crystalline AS particle surface due to the adsorbed water. The behavior of BSA particles (nominally a non-crystalline amorphous solid) differs considerably from that of AS particles. The BSA bounce does not show similar clear decrease with increasing humidity. The difference in the BSA and AS behavior lies in the differences in material characteristics: adsorbed water forms a layer on the surface of solid crystalline, stable structured AS particles, while in the case of amorphous solid BSA particles the adsorbed water molecules can diffuse into the particle bulk. According to Shiraiwa et al. (2011) the estimated viscosity for BSA is $10^{12}-10^{10} \mathrm{Pas}$ in the studied viscosity range (the viscosity of glassy material is $10^{12} \mathrm{Pas}$ ).

Finally, the BF behavior of levoglucosane particles (LG) with increasing RH is shown. Amorphous levoglucosane particles show a gradual decrease in bounce with increasing RH in the range $30-60 \%$. This decrease in bounce can be related to the gradual humidity induced phase transition described in Mikhailov et al. (2009). Despite these three different compounds show a clear trend in $\mathrm{BF}$ with respect to $\mathrm{RH}$, it is currently not possible (and out of the scope of this paper) to define specific and absolute BF threshold values to describe possible particle phase transitions (i.e. from solid amorphous to semi-solid amorphous to liquid). 
Table 1. SOA generation parameters and measurements. The third $\alpha$-pinene line with ${ }^{*} \mathrm{OH}$ exposure of 0 refers to an ozonolysis experiment.

\begin{tabular}{lrrrrrr}
\hline & $\begin{array}{r}* \text { OH exposure } \\
\text { Precursor(s) }\end{array}$ & & & & & \\
& $\left(10^{11} \mathrm{molec}^{-3} \mathrm{~s}\right)$ & $\mathrm{O} / \mathrm{C}$ & $\mathrm{H} / \mathrm{C}$ & $\kappa$ & Std. dev. O/C. & Std. dev. H/C \\
\hline Isoprene & 22.0 & 0.62 & 1.7 & 0.21 & 0.003 & 0.007 \\
Isoprene & 7.82 & 0.61 & 1.75 & 0.15 & 0.002 & 0.005 \\
$\alpha$-pinene & 15.5 & 0.69 & 1.36 & 0.19 & 0.004 & 0.004 \\
$\alpha$-pinene & 11.4 & 0.55 & 1.45 & 0.17 & 0.002 & 0.003 \\
$\alpha$-pinene & 0 & 0.34 & 1.52 & 0.14 & 0.003 & 0.001 \\
Longifolene & 22.0 & 0.58 & 1.31 & 0.19 & 0.003 & 0.002 \\
Longifolene & 2.77 & 0.14 & 1.53 & 0.05 & 0.002 & 0.001 \\
Longifolene+SO & 22.0 & 0.55 & 1.77 & 0.19 & 0.003 & 0.004 \\
Longifolene+ $\mathrm{SO}_{2}$ & 22.0 & 0.57 & 1.74 & 0.17 & 0.006 & 0.004 \\
Longifolene+SO & 22.0 & 0.75 & 1.49 & 0.21 & 0.004 & 0.003 \\
Naphthalene & 22.0 & 1.41 & 0.90 & 0.18 & 0.005 & 0.002 \\
Naphthalene & 7.82 & 0.68 & 0.97 & 0.15 & 0.006 & 0.005 \\
Naphthalene & 2.77 & 0.35 & 0.92 & 0.16 & 0.003 & 0.004 \\
$n$-heptadecane & 11.4 & 0.30 & 1.69 & 0.12 & 0.003 & 0.006 \\
$n$-heptadecane & 7.82 & 0.20 & 1.78 & 0.11 & 0.002 & 0.003 \\
$n$-heptadecane & 4.95 & 0.15 & 1.85 & 0.04 & 0.001 & 0.003 \\
$n$-heptadecane & 2.77 & 0.10 & 1.92 & 0.01 & 0.001 & 0.003 \\
\hline
\end{tabular}

Semi-solid/solid amorphous materials have very wide viscosity range. By definition the viscosity of the liquids is $<102$ Pas, viscosity of the semisolids varies from $10^{2}$ Pas up to $10^{12}$ Pas. Material having viscosity $>10^{12}$ Pas can be considered as "glass" (e.g. Koop et al., 2011). Thus "more solid" refers to the (amorphous) material having higher viscosity and higher BF value than some other (amorphous) material.

\subsection{Phase state and humidity-induced phase transitions of biogenic SOA particles}

The fraction of bounced SOA particles formed from biogenic precursors (isoprene, $\alpha$-pinene, and longifolene) as a function of $\mathrm{RH}$ in the impactor is shown in Fig. 4. As mentioned in Sect. 2.2, the relative humidity in the impactor is approximately $30 \%$ lower than the initial humidified sample RH because of the pressure drop in the impactor stage. Therefore we define the $\mathrm{RH}$ value inside the impactor as the impactor $\mathrm{RH}$, or $\mathrm{RH}_{I}$.

For $20 \%<\mathrm{RH}_{I}<50 \%$, the bounced fraction of biogenic SOA particles was between 0.65 and 0.9 in all cases and for all $\mathrm{O} / \mathrm{C}$ levels ranging from 0.14 to 0.69 . Thus, we conclude that biogenic SOA particles generated in the PAM reactor are solid or semi-solid at $\mathrm{RH}_{I}<50 \%$ over the range of measured conditions. For $\mathrm{RH}_{I}>50 \%$, the measured BF of biogenic SOA particles decreased. This decrease in bounce suggests a decrease in viscosity as a result of a humidity-induced phase change from solid to liquid-like particles. It should be noted that in the case of highly viscous, glassy particles the possibility of formation of liquid layer of adsorbed water on the particle surface can not be entirely excluded. The formation of such a layer may then reduce the bounced fraction of the particles. The HTDMA studies of SOA particles, how- ever show modest but gradual particle water uptake with increasing humidity (Varutbangkul et al., 2006; Prenni et al., 2007). This behaviour suggests that water uptake is not pure adsorption only, but the water is able to diffuse to the particle bulk.

The decrease in $\mathrm{BF}$ above $\mathrm{RH}_{I}$ of $55 \%$ was most pronounced for isoprene SOA particles for which BF decreased to $0.25 \pm 0.1$ at $\mathrm{RH}_{I}=65 \%$ (Fig. 4, top panel). The BF vs $\mathrm{RH}_{I}$ relatiosnhip in the case of isoprene could only be explored for one $\mathrm{O} / \mathrm{C}$ value (0.61). However, similar measurements of bounced fraction as a function of $\mathrm{RH}_{I}$ performed for SOA particles generated from $\alpha$-pinene (Fig. 4 middle panel) and longifolene (Fig. 4 lower panel) showed that there was no systematic difference in the measured bounced fraction for as a function of $\mathrm{O} / \mathrm{C}$ ratio $(\mathrm{O} / \mathrm{C}=0.34$ to 0.69 for $\alpha$-pinene and 0.14 to 0.58 for longifolene SOA). For SOA particles generated from $\alpha$-pinene, the bounced fraction decreased from $0.75 \pm 0.1$ (at $\mathrm{RH}_{I} \sim 22 \%$ ) to $0.55 \pm 0.1$ (at $\mathrm{RH}_{I}=65 \%$ ). For SOA particles generated from longifolene, the bounced fraction decreased from $0.78 \pm 0.05$ to $0.7 \pm 0.1$ across the same $\mathrm{RH}_{I}$ range. These decreases in bounce were significantly less than for SOA produced from isoprene, suggesting that phase changes were less pronounced.

It appears that for these three biogenic SOA types, the $\mathrm{RH}_{I}$-dependent decrease in BF became less pronounced with increasing molar mass of the precursor. The observation for $\alpha$-pinene and levoglucosan SOA of high bounce at the higher RHs are in line with the growth factors reported by Varutbangkul et al. (2006) (1.01-1.02 for monoterpenes, less than 1.01 for most sesquiterpenes at $50 \% \mathrm{RH}$ ), as well as the observed higher bounce of longifolene versus $\alpha$-pinene SOA. 


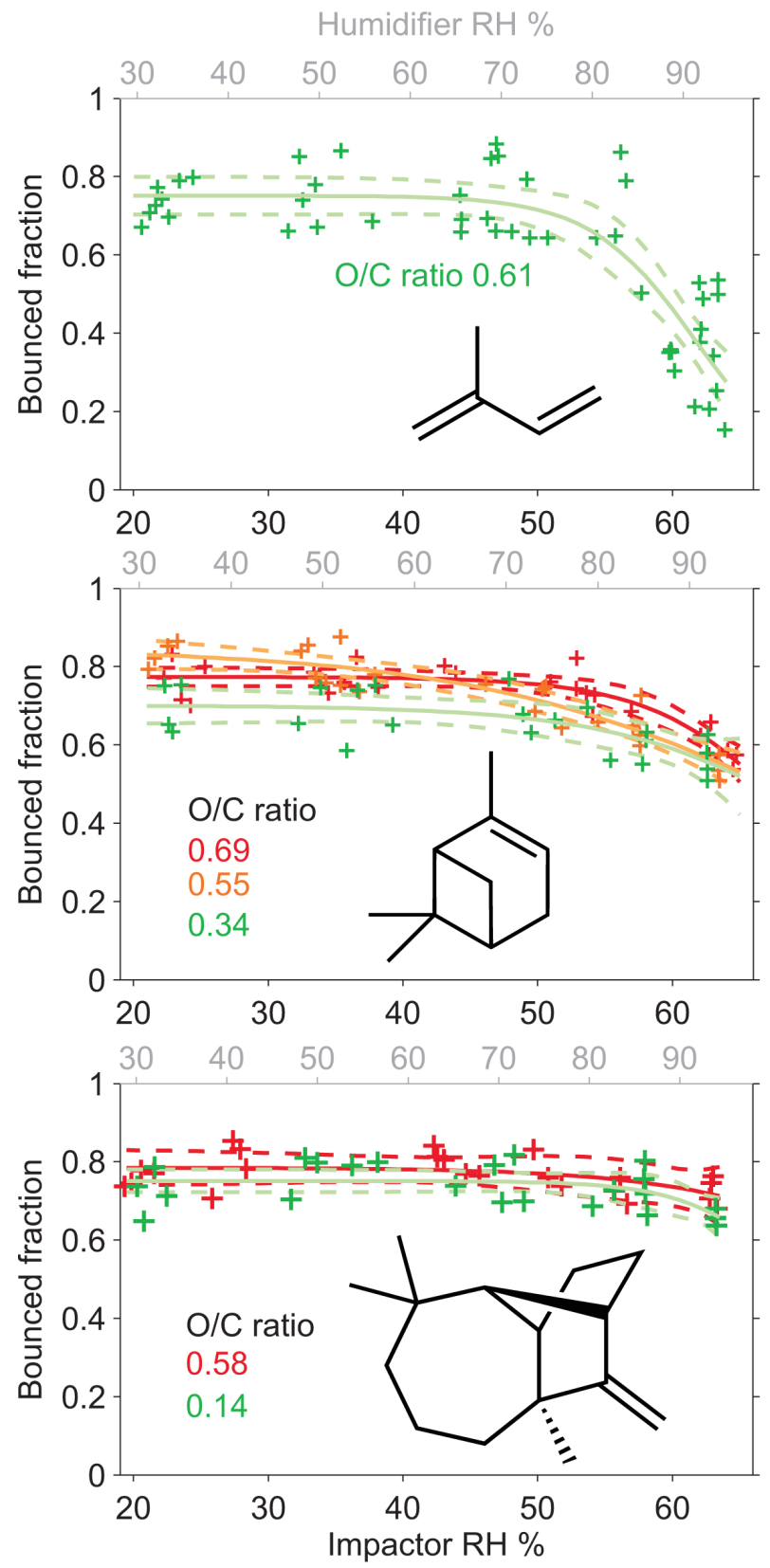

Fig. 4. Bounce behavior of SOA from photo-oxidation experiments of biogenic precursors, solid lines are sigmoid fits to guide the eye, dashed lines give the $95 \%$ confidence bounds for the fits. Upper panel: isoprene SOA, middle panel: $\alpha$-pinene SOA, lower panel: longifolene SOA.

\subsection{Phase state and humidity-induced phase transitions of mixed SOA-sulphuric acid particles}

In most cases, ambient oxygenated organic aerosol (OOA) is mixed with inorganic species such as particulate nitrate and sulphate, (e.g. Jimenez et al., 2009), which may influence the viscosity or phase of the aerosols. In a separate set of exper- iments, we measured the bounced fraction of SOA/sulphuric acid mixtures generated from the simultaneous oxidation of longifolene and $\mathrm{SO}_{2}$ in the PAM reactor. The longifolene system was chosen because the bounced fraction of longifolene SOA resulted particularly insensitive to increasing $\mathrm{RH}_{I}$ (cf. Fig. 4). Therefore, any changes in particle bounce are due to changes in the organics-to-sulphate ratio of the particles (measured by the HR-ToF-AMS).

It is important to consider that in the case of multicomponent inorganic-organic particles it is possible that a liquid-liquid phase separation may occur (Marcolli and Krieger, 2006; Ciobanu et al., 2009; Bertram et al., 2011; Song et al., 2012; Zuend and Seinfeld, 2012). Since we cannot distinguish phase separation in the $100 \mathrm{~nm}$ particles studied here, we discuss below whether the observed bounce behavior is consistent with one or both of the two possible cases, i.e. liquid-liquid phase-separated aerosol particles and well-mixed aerosol particles.

Figure 5 shows the measured bounced fraction as a function of $\mathrm{RH}_{I}$ for longifolene SOA-sulphate mixtures, with sulphate mass fractions ranging from 0.09 to 0.36 . The sulfate fraction is calculated as the fraction of sulfate mass with respect to the measured AMS total mass (mostly ORG, with small concentrations of $\mathrm{NH}_{4}$ within instrumental noise). The $\mathrm{O} / \mathrm{C}$ measured for the pure longifolene SOA was 0.58 , and with sulfate fractions of $0.9,0.20$ and 0.36 the respective $\mathrm{O} / \mathrm{C}$-ratios were $0.55,0.57$ and 0.75 while keeping other parameters constant.

As is evident from Fig. 5, a sulphate mass fraction of 0.09 does not decrease the particle bounce relative to that of pure longifolene SOA. However, increasing the sulphate mass fraction to 0.20 results in a continual decrease in particle bounced fraction as a function of $\mathrm{RH}_{I}$, with the sharpest decrease at $\mathrm{RH}_{I} 55 \%$, to a final bounced fraction of $0.1 \pm 0.05$ at $\mathrm{RH}_{I}=62 \%$. This suggests a solid-to-liquid phase transition of the mixed SOA/sulfate particles in this range of $\mathrm{RH}_{I}$. Increasing the sulphate mass fraction to 0.36 results in a constant particle bounced fraction $0.10 \pm 0.05$ for $20 \%<\mathrm{RH}_{I}<62 \%$, suggesting a liquid-like behavior over the entire $\mathrm{RH}_{I}$ range investigated.

The HR-ToF-AMS particle time-of-flight measurements confirmed that the SOA and sulphate were internally mixed in all cases and particle sizes. As noted above, liquid-liquid phase separation may occur in aerosol particles consisting of organic and inorganic species. In the present SA/SOA case, this would result in one phase consisting predominantly of SA with minor contributions from organics, and another phase that is organic-rich but also contains significant SA (typically between 10 to $30 \%$ of dry solute mass, see Song et al., 2012). Moreover, the organic phase is very likely to constitute the outer phase, while the inorganic SA phase is more likely to be located in the core of a particle due to a minimization of the overall surface energy of the particle (Krieger et al., 2012). At room temperature SA/water mixtures are liquid over the entire concentration range. Hence, 


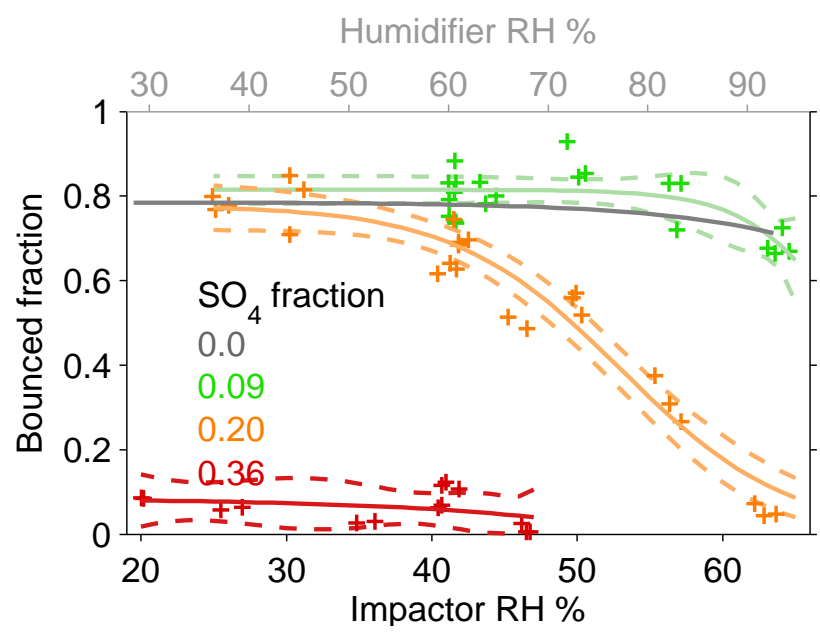

Fig. 5. Addition of $\mathrm{SO}_{2}$ to precursor flow for longifolene SOA experiment decreases the phase transition relative humidity. The $\mathrm{SO}_{4}$ fraction indicates the fraction of $\mathrm{SO}_{4}$ with respect to the total measured AMS mass $\left(\mathrm{ORG}+\mathrm{SO}_{4}+\mathrm{NO}_{3}+\mathrm{NH}_{4}\right)$.

the particle core may be liquid for the entire range of investigated humidity studied here. In contrast, the organic-rich outer "shell" consisting of SOA/SA mixtures might be in a solid, semi-solid or liquid state depending on experimental conditions. For the case of a sulphate fraction of 0.09 it appears that the bounce is very similar to that of pure SOA particles suggesting that neither the minor inorganic fraction contained in the outer shell nor the liquid SA core significantly decrease the bounce of the particle. For a larger SA fraction of 0.2 the reduced bounce at higher humidity suggests at least a partial liquefaction. This might have two causes. First, the liquid core is larger due to an enhanced SA content when compared to the 0.09 SA case and, hence, more significant water uptake occurs at higher humidity. Secondly, in addition a larger SA content in the organic outer shell might reduce its viscosity when compared to the pure SOA particle phase. Finally, at an SA content of 0.36 the particles show a liquid-like bounced fraction over the entire humidity range. Again this might indicate an even larger SA core that is liquid-like even at low humidity and in addition a possible further increased SA content in the organic shell, also further reducing the outer organic shell's viscosity even at lower humidity.

The behavior of longifolene SOA/sulphuric acid mixtures seen in Fig. 5 might therefore be attributed to the particles' SA core being liquid, with potential effects of SA also in the organic shell. As far as the liquid content is concerned, a very rough estimate of the liquid content (water and sulfuric acid) can be made by assuming phase separation and water uptake of sulphuric acid according to Kim et al. (1994). Based on this, the water $+\mathrm{H}_{2} \mathrm{SO}_{4}$-volume concentration of the particles is above $60 \%$ for the case of $0.36 \mathrm{SO}_{4}$ fraction, and below $31 \%$ for the case of $0.09 \mathrm{SO}_{4}$ fraction. The intermediate case of $\mathrm{SO}_{4}$ fraction of 0.20 has the water $+\mathrm{H}_{2} \mathrm{SO}_{4}$-volume concentration ranging from 0.46 at $30 \% \mathrm{RH}$ to 0.52 at 0.52 at $60 \% \mathrm{RH}_{I}$.

For these reasons, it is useful to discuss how increasing sulphate content would affect the phase state of well-mixed SOA/SA particles. In principle, empirical mixing laws that are based on data from various mixtures of a range of different compounds predict that the glass transition temperature $\left(T_{\mathrm{g}}\right)$ of a mixture is between the $T_{\mathrm{g}}$ 's of the individual compounds (Koop et al., 2011). However, this has not been confirmed so far for a sulphuric acid /organic mixture. Therefore, the principle behavior of well-mixed organic/sulphate solutions was further examined using differential scanning calorimetry (DSC) (Höhne et al., 2003) by measuring $T_{\mathrm{g}}$ of a model mixtures of glucose and sulphuric acid, for experimental details see Zobrist et al. (2008). (We were not able to use SOA material for such purposes, because the SOA sample mass required for such measurements is in the microgram range and thus far beyond that available from the PAM reactor.) Figure 6 shows that increasing the mass fraction of sulphuric acid decreases the glass transition temperature of the mixture at constant solute mass fraction (i.e. constant water content). Our results are therefore consistent with studies showing that mixing compounds with different $T_{\mathrm{g}}$ values normally results in a glass transition temperature of the mixture that is between $T_{\mathrm{g}}$ values of the individual mixture components (Zobrist et al., 2008; Koop et al., 2011).

Accordingly, because sulphuric acid shows a lower $T_{\mathrm{g}}$ than the SOA organics investigated here, its presence would soften the SOA particles. Moreover, owing to its larger hygroscopicity sulphuric acid (and similarly ammonium bisulfate or ammonium sulfate) also leads to an increase in water content of the particles at the same RH, further softening the particles, thereby leading to a humidity-induced liquefaction of the particles at humidities that are lower when compared to those of pure SOA particles. This is shown schematically in the bottom panel of Fig. 6 , which is a sketch of $T_{\mathrm{g}}$ versus equilibrium relative humidity for various organics and/or sulphuric acid mixtures. When humidity is increased at constant temperature (black arrow) the pure organic (green curve) with the highest glass transition temperature in the dry state, $T_{\mathrm{g}}$ (dry), shows a humidity-induced liquefaction at the highest RH (intersection between the black arrow and the green $T_{\mathrm{g}}$ curve), close to the upper end of investigated $\mathrm{RH}$ range. In contrast, pure sulphuric acid or a mixture with high sulphuric acid content (red) show the lowest $T_{\mathrm{g}}$ (dry) and, hence, are liquid over the full range of investigated $\mathrm{RH}$ without any bounce. Finally, a mixture with a high organics content (orange) shows an intermediate $T_{\mathrm{g}}$ (dry), thus liquefying at an intermediate $\mathrm{RH}$ in the middle of the investigated RH range.

We conclude that both principle types of particle morphology, i.e. liquid-liquid phase-separated particles and also wellmixed particles are able to describe the observed bounce behavior of SOA/SA particles. We further note, that if sulphuric 

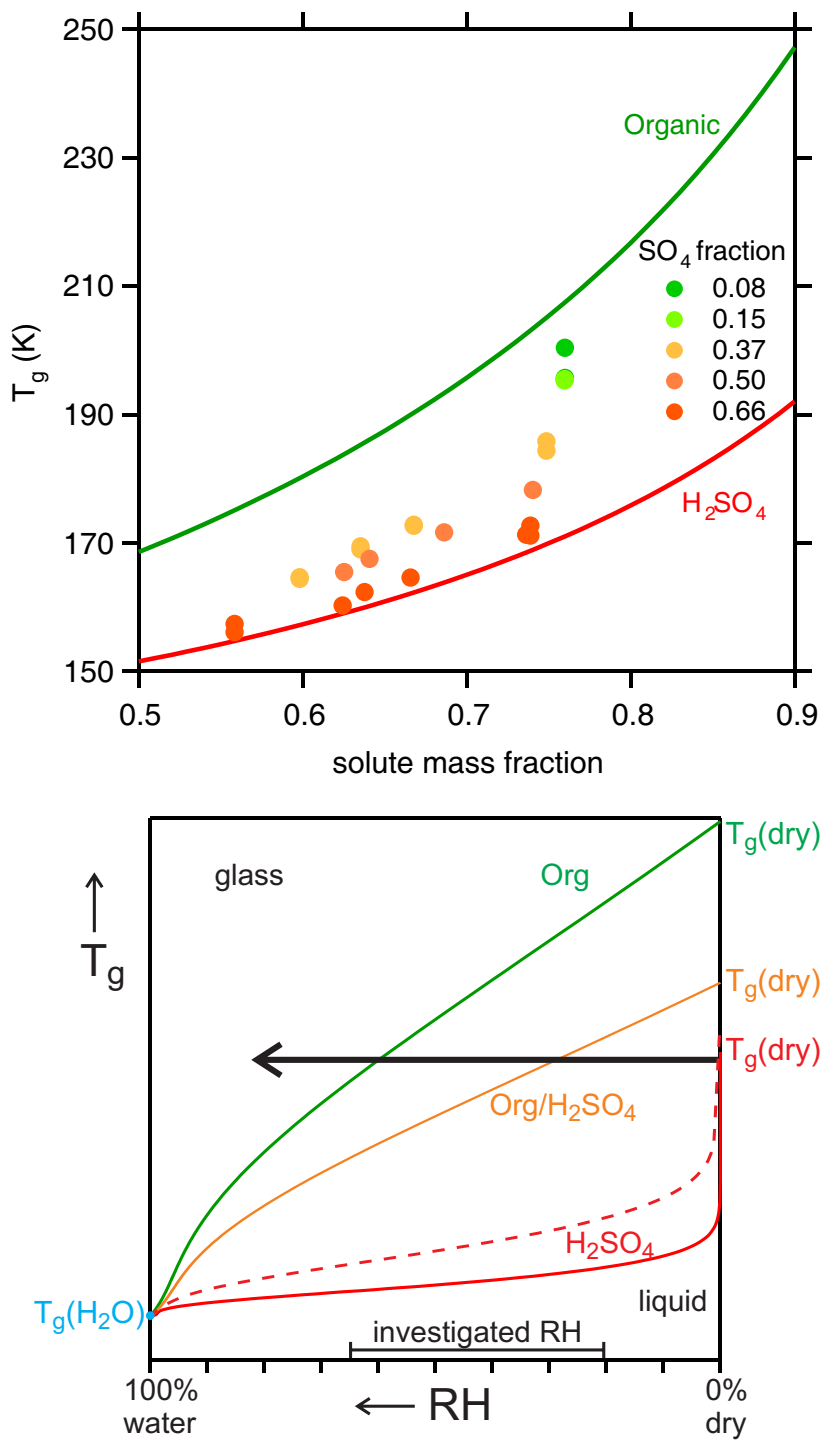

Fig. 6. Top: addition of $\mathrm{H}_{2} \mathrm{SO}_{4}$ to an organic (here: glucose) leads to a strong reduction in $T_{\mathrm{g}}$ at the same water content (Pedernera, 2008). The effect is even more pronounced when plotted as a function of relative humidity (because of the different hygroscopicities of organics and sulfate). The bottom panel is a schematic picture of $T_{\mathrm{g}}$ versus equilibrium relative humidity for various organic/sulphuric acid mixtures.

acid plays an important role in atmospheric nucleation processes, as suggested by Sipilä et al. (2010) and Kirkby et al. (2011), our results suggest that freshly nucleated particles containing appreciable amounts of sulphuric acid are initially liquid. The discussion above indicates that this might be true independently of whether the sulphate and organic fraction are phase-separated or not. As the particles grow via condensation of oxygenated organic species, the mass fraction and, hence, the effective $T_{\mathrm{g}}$ might increase and the particles may solidify (Virtanen et al., 2010, 2011).

\subsection{Phase state and humidity-induced phase transitions of anthropogenic SOA particles}

In addition to bounce measurements of biogenic SOA particles, we also studied the bounce behavior of anthropogenic SOA particles generated from the oxidation of naphthalene and $n$-heptadecane. Naphthalene was chosen as a model aromatic precursor, and $n$-heptadecane as a model aliphatic precursor. The upper panel in Fig. 7 shows the bounced fraction of SOA particles generated from naphthalene as a function of $\mathrm{RH}_{I}$. The bounce behavior for naphthalene SOA is similar to that of $\alpha$-pinene SOA, with a decrease in bounced fraction from $0.65 \pm 0.1$ (average value among several $\mathrm{O} / \mathrm{C}$ ratios) at $\mathrm{RH}_{I}<50 \%$ to $0.4 \pm 0.1$ at $\mathrm{RH}_{I}=64 \%$.

The lower panel in Fig. 7 shows the bounce behavior of $n$ heptadecane $\mathrm{SOA}$ as a function of $\mathrm{RH}_{I}$. Unlike the other systems that were studied, the bounced fraction of SOA particles generated from $n$-heptadecane was strongly correlated with the $\mathrm{O} / \mathrm{C}$ ratio of the SOA. At $\mathrm{O} / \mathrm{C}=0.10$, the $\mathrm{SOA}$ bounced fraction was low $(0.2 \pm 0.05)$ and was unaffected by $\mathrm{RH}_{I}$, implying an organic liquid-like phase. At $\mathrm{O} / \mathrm{C}=0.15$, the bounced fraction was above 0.5 at $\mathrm{RH}_{I}=20 \%$ and exhibited a monotonic decrease to slightly below 0.3 at $\mathrm{RH}_{I}=64 \%$. At $\mathrm{O} / \mathrm{C}=0.20$, a constant bounced fraction of $0.55 \pm 0.05$ was measured for $\mathrm{RH}_{I}<50 \%$, with a decrease in bounced fraction to 0.4 at $\mathrm{RH}_{I}=64 \%$. Finally, at an $\mathrm{O} / \mathrm{C}$ ratio of 0.30 , we measured a constant bounced fraction of above 0.8 at $\mathrm{RH}_{I}<50 \%$ before the bounced fraction decreased to below 0.7 at $\mathrm{RH}_{I}=60 \%$. This bounce behavior was similar to that observed in the other systems that were studied. Thus, SOA particles generated from $n$-heptadecane were initially liquid-like at low $\mathrm{O} / \mathrm{C}$ ratio and solidified with increasing $\mathrm{O} / \mathrm{C}$ ratio.

In order to rationalize the observed behavior of the anthropogenic SOA particles, in Fig. 8 we show the predicted $T_{\mathrm{g}}$ values for naphthalene $(\sim 247 \mathrm{~K})$ and $n$-heptadecane $(\sim 207 \mathrm{~K})$. These $T_{\mathrm{g}}$ values were predicted from the observed dependence of $T_{\mathrm{g}}$ upon melting temperature $\mathrm{T}_{m}$, i.e. $T_{\mathrm{g}} \approx$ $0.7 \times T_{\mathrm{m}}$ (Koop et al., 2011). Also shown in Fig. 8 are the predicted $T_{\mathrm{g}}$ for various oxygenated compounds originating from the parent structure of $n$-heptadecane (red) and naphthalene (blue). The red-shaded and blue-shaded vertical bars indicate the range of investigated $\mathrm{O} / \mathrm{C}$ ratio for each SOA. The grey horizontal bar indicates the suggested turnover from liquid behavior at room temperature (no bounce) for substances with a $T_{\mathrm{g}}$ less than $\sim 250 \mathrm{~K}$ to solid behavior (bounce) for substances with a $T_{\mathrm{g}}$ above $\sim 270 \mathrm{~K}$.

The predicted $T_{\mathrm{g}}$ of naphthalene is already close to $250 \mathrm{~K}$, and just adding one O-atom (e.g. 1-naphthol and 2-naphthol, with an $\mathrm{O} / \mathrm{C}$ ratio of 0.1 ) might initiate (partial) bounce in such particles at room temperature. Further increase in $\mathrm{O} / \mathrm{C}$ ratio to values between $0.2-0.4$ leads to predicted $T_{\mathrm{g}}$ values from close to room temperature up to significantly beyond room temperature, implying full bounce. Even though there is considerable scatter in these data, it is obvious that in the 


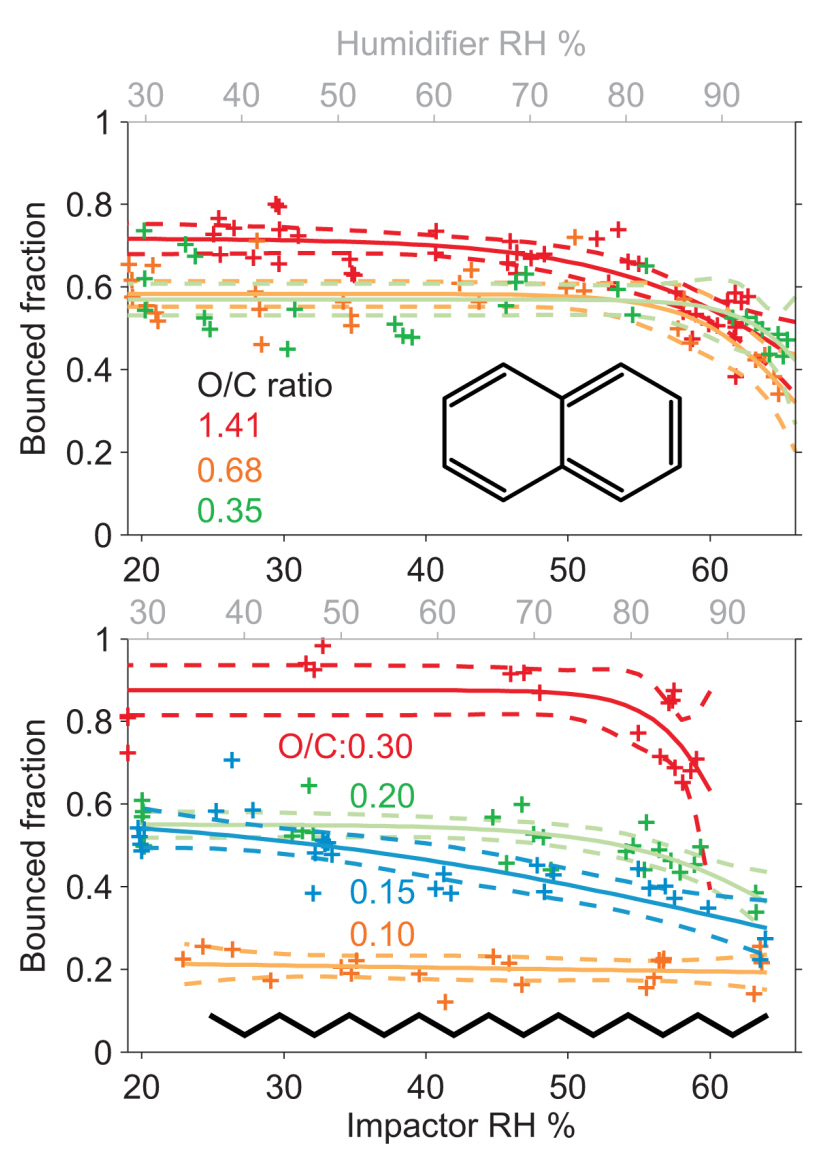

Fig. 7. Bounce behavior of SOA from photo-oxidation of naphthalene (upper panel) and $n$-heptadecane (lower panel).

measured range of $\mathrm{O} / \mathrm{C}>0.35$ (light blue shading) nearly all substances are expected to bounce independently of their actual $\mathrm{O} / \mathrm{C}$ ratio.

In contrast, the predicted $T_{\mathrm{g}}$ for $n$-heptadecane and those of mildly oxygenated compounds (1-alcohol, 1-aldehyde, 2ketone) with an $\mathrm{O} / \mathrm{C}$ ratio of 0.06 are so low that these compounds are liquid at room temperature and, thus, would not show bounce. Only at significant oxygenation (e.g. the 1,17dicarboxylic acid, with an $\mathrm{O} / \mathrm{C}$ ratio of 0.24 ) bounce is to be expected. We note that oxygenation of $n$-heptadecane is likely to lead to fragmentation (Lambe et al., 2012). However, it appears that at least an oxidation to a dicarboxylic acid is required for bounce, more or less independently of the length of the remaining carbon chain (see red open circles with number of C-atoms indicated). For $n$-heptadecane, the $T_{\mathrm{g}}$ goes from $\sim 207 \mathrm{~K}$ to greater than $\sim 280 \mathrm{~K}$ with increasing $\mathrm{O} / \mathrm{C}$ (pink shading), in agreement with the measurements.

Similarly to previous studies that suggest a correlation of bounced fraction with the glass transition temperature (Virtanen et al., 2010) the same correlation is observed here. Based on an idealized comparison of predicted $T_{\mathrm{g}}$ values shown

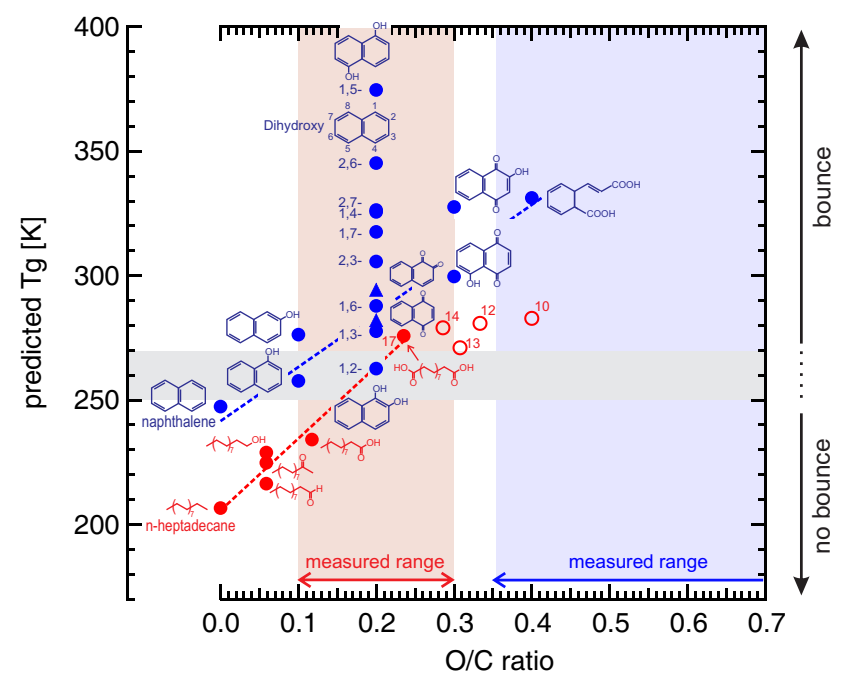

Fig. 8. Predicted glass transition temperatures $T_{\mathrm{g}}$ as a function of the molecular $\mathrm{O} / \mathrm{C}$ ratio for various oxygenated compounds originating from the parent structure of $n$-heptadecane (red) and naphthalene (blue). Open circles are predicted $T_{\mathrm{g}}$ for $n$-dicarboxylic acids with the number of $\mathrm{C}$-atoms indicates for each point. For details see text.

in Fig. 8, it is no surprise that $n$-heptadecane SOA shows a "bounce transition" with increasing $\mathrm{O} / \mathrm{C}$ in the investigated range while naphthalene SOA bounced at all investigated $\mathrm{O} / \mathrm{C}$ ratios.

\subsection{Discussion}

The main factors affecting the bounce behavior of SOA particles are likely their viscosity, elasticity and the surface adhesion. For amorphous particles, the viscosity and mechanical properties are sensitive to the glass transition temperature (Shiraiwa et al., 2011; Koop et al., 2011). The glass transition temperature and thus the viscosity at constant temperature are sensitive to the solvent concentration, molar mass and the functional groups of the particulate matter (Zobrist et al., 2008; Koop et al., 2011). As discussed above, we suggest that humidity-induced changes in bounced fraction of the SOA particle are related to a humidity-induced glass transition of SOA particles (Mikhailov et al., 2009).

The conditions for a humidity-induced glass transition (i.e. liquefaction) are connected to $T_{\mathrm{g}}$ (dry) of the SOA compounds at dry conditions, which is correlated to the molar mass of the compounds. Therefore, we attempt to relate the measured humidity-induced phase transitions of the SOA particles to their molar mass by showing the slope of the bounced fraction of SOA particles at $\mathrm{RH}_{I}>50 \%$ as a function of precursor molar mass (Fig. 9). Markers are colored by the O/C ratio of the SOA. Fig. 9 shows that for SOA particles produced from isoprene, $\alpha$-pinene, longifolene, and naphthalene, the "bounce slope" was correlated with the precursor molar mass. Similar trend between precursor molecular 


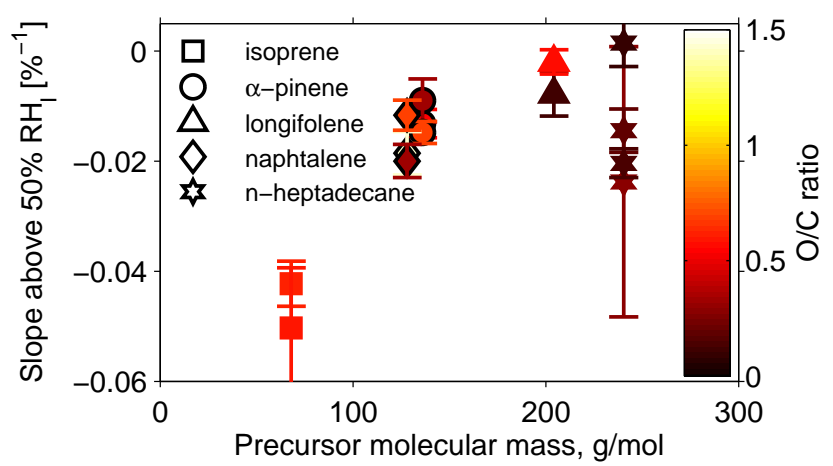

Fig. 9. The slope of the bounce at $\mathrm{RH}_{I}>50 \%$ versus precursor molar mass for the studied systems. Error bars mark the standard error of the slope of each fit.

mass and SOA particle growth factor was also shown by Varutbangkul et al. (2006). SOA particles produced from $n$ heptadecane did not follow the same trend as the particles generated by the other precursors.

According to several studies SOA particles may contain oligomers, polymers and other high molecular weight molecules (Tolocka et al., 2004; Gao et al., 2004; Kalberer et al., 2004; Hallquist et al., 2009; Hall IV and Johnston, 2011; Kundu et al., 2012). Such oligomers and polymers are likely to affect the phase state of SOA particles. There is experimental evidence from different types of materials that oligomerisation and polymerisation do lead to an increase of the glass transition temperature of a chemical compound, and semi-empirical formulations exist (e.g., the Fox-Flory relation) that describe the molar mass dependence of $T_{\mathrm{g}}$ (Fox and Flory, 1950; Rietsch et al., 1976; Koop et al., 2011). Moreover, there is also mounting evidence that cross-linking of polymers also leads to an increase in $T_{\mathrm{g}}$ when compared to the same linear polymer, independently of whether the polymers are cross-linked in a linear or even branched fashion (Nielsen, 1969; Rietsch et al., 1976), owing to a reduced segmental motion of the individual monomeric chain units. This, oligomer and polymer formation in SOA particles will normally favor the formation of semi-solid or solid amorphous phases. It should be noted, however, that oligomeric compounds do not automatically lead to the formation of amorphous solids at room temperature. For example, in a recent study by Perraud et al. (2012) it was shown that, in contrast to $\alpha$-pinene SOA, aerosolized poly(ethyleneglycol) oligomers (PEG 400 , molar mass $\sim 400 \mathrm{~g} \mathrm{~mol}^{-1}$, equivalent to 9 repeating units) did show liquid-like behavior in terms of their phase partitioning of oxidation products, in agreement with the fact that PEG 400 is liquid and known to be a good plasticizer for polymers. Thus the chemical nature of oligomers in SOA as well as their mass fraction in the organic phase of a particle is crucial to quantify their effect on the formation of amorphous solids. To obtain such detailed data is beyond the present study, as the HR-ToF-AMS does not retain in- formation regarding high MW compounds and/or oligomers in the SOA due to the high degree of fragmentation of the molecular vapor via standard electron impact (Canagaratna et al., 2007), and is an interesting topic for future studies. To the extent that the "bounce slope" is proportional to the average molar mass (AMM) of the SOA, Fig. 9 suggests that the AMM of SOA generated from $n$-heptadecane does not scale with precursor AMM in the same way as the SOA in the other experiments. One possible explanation for this observation is that fragmentation reactions that cleave carbon-carbon bonds and lower the AMM are more important in SOA produced from $n$-heptadecane than in the other systems. The importance of fragmentation reactions has not been extensively characterized for precursors studied in this work. However, Chacon-Madrid et al. (2010) and Chacon-Madrid and Donahue (2011) showed that the * $\mathrm{OH}$ oxidation of linear aldehydes/ketones formed SOA in lower yields than linear alkanes with equivalent vapor pressures, suggesting that fragmentation is important for SOA generated from alkane precursors. If SOA generated from the other precursors experienced less fragmentation than SOA generated from $n$-heptadecane, this may explain the trends observed in Fig. 9.

\section{Conclusions}

Our results suggest that most types of atmosphericallyrelevant SOA form amorphous solid or semi-solid particles at $\mathrm{RH}_{I} \lesssim 60 \%$. These SOA particles can undergo phase transitions as a result of changes in relative humidity, and/or $\mathrm{O} / \mathrm{C}$ level. Addition of hygroscopic sulphuric acid to the SOA liquefied the mixed particles at low $\mathrm{RH}_{I}$, which is consistent with aerosol bounce observations from Virtanen et al. (2011) and $T_{\mathrm{g}}$ measurements from Koop et al. (2011). The phase of the SOA affects corresponding timescales for mass transfer and heterogeneous reactions within the particles (Cappa and Wilson, 2011; Vaden et al., 2011; Shiraiwa et al., 2011), and may influence their ability to serve as cloud condensation nuclei or ice nuclei in the atmosphere.

In most cases, humidity-induced phase changes measured for the SOA were not correlated with $\mathrm{O} / \mathrm{C}$ ratio or the $\mathrm{CCN}$ activity, $\kappa$. However, our measurements suggest that humidity-induced phase changes were related to the average molar mass of the SOA. These observations are consistent with the results of Koop et al. (2011), who showed that $T_{\mathrm{g}}$ was more strongly influenced by molar mass than $\mathrm{O} / \mathrm{C}$ ratio of model organic compounds.

With the exception of SOA produced from $n$-heptadecane, the bounced fraction of SOA particles at $\mathrm{RH}_{I}<50 \%$ was insensitive to changes in $\mathrm{O} / \mathrm{C}$ ratio. The increase in bounced fraction of $n$-heptadecane SOA particles as a function of $\mathrm{O} / \mathrm{C}$ ratio is consistent with an oxidation-induced phase change from organic liquid particles to organic semi-solid particles. Future work will investigate the prevalence of oxidation-induced phase changes in other types of SOA, as 
well as the ability of the bounce measurement to provide quantitative measurements of particle viscosity, diffusivity, and glass transition temperature.

Acknowledgements. This work was supported by a grant from the Nessling Foundation to the Tampere University of Technology. The research was also supported by the Office of Science (BER), Department of Energy (Atmospheric Science Program) grant No. DE-SC0006980 and the Atmospheric Chemistry Program of the National Science Foundation grants No. ATM-0525355 and ATM-0854916 to Boston College and Aerodyne Research, Inc, and the EU integrated project 505390-GOCE-CT-2004.

Edited by: B. Ervens

\section{References}

Aiken, A. C., DeCarlo, P. F., and Jimenez, J. L.: Elemental Analysis of Organic Species with Electron Ionization HighResolution Mass Spectrometry, Anal. Chem., 79, 8350-8358, doi:10.1021/ac071150w, 2007.

Aiken, A. C., DeCarlo, P. F., Kroll, J. H., Worsnop, D. R., Huffman, J. A., Docherty, K. S., Ulbrich, I. M., Mohr, C., Kimmel, J. R., Sueper, D., Sun, Y., Zhang, Q., Trimborn, A., Northway, M., Ziemann, P. J., Canagaratna, M. R., Onasch, T. B., Alfarra, M. R., Prevot, A. S. H., Dommen, J., Duplissy, J., Metzger, A., Baltensperger, U., and Jimenez, J. L.: O / C and OM/OC Ratios of Primary, Secondary, and Ambient Organic Aerosols with HighResolution Time-of-Flight Aerosol Mass Spectrometry, Environ. Sci. Technol., 42, 4478-4485, doi:10.1021/es703009q, 2008.

Bertram, A. K., Martin, S. T., Hanna, S. J., Smith, M. L., Bodsworth, A., Chen, Q., Kuwata, M., Liu, A., You, Y., and Zorn, S. R.: Predicting the relative humidities of liquid-liquid phase separation, efflorescence, and deliquescence of mixed particles of ammonium sulfate, organic material, and water using the organic-to-sulfate mass ratio of the particle and the oxygen-tocarbon elemental ratio of the organic component, Atmos. Chem. Phys., 11, 10995-11006, doi:10.5194/acp-11-10995-2011, 2011. Canagaratna, M., Jayne, J., Jimenez, J., Allan, J., Alfarra, M., Zhang, Q., Onasch, T., Drewnick, F., Coe, H., Middlebrook, A., Delia, A., Williams, L., Trimborn, A., Northway, M., DeCarlo, P., Kolb, C., Davidovits, P., and Worsnop, D.: Chemical and microphysical characterization of ambient aerosols with the aerodyne aerosol mass spectrometer, Mass Spectrom. Rev., 26, 185-222, doi:10.1002/mas.20115, 2007.

Cappa, C. D. and Wilson, K. R.: Evolution of organic aerosol mass spectra upon heating: implications for OA phase and partitioning behavior, Atmos. Chem. Phys., 11, 1895-1911, doi:10.5194/acp11-1895-2011, 2011.

Chacon-Madrid, H. J. and Donahue, N. M.: Fragmentation vs. functionalization: chemical aging and organic aerosol formation, Atmos. Chem. Phys., 11, 10553-10563, doi:10.5194/acp11-10553-2011, 2011.

Chacon-Madrid, H. J., Presto, A. A., and Donahue, N. M.: Functionalization vs. fragmentation: n-aldehyde oxidation mechanisms and secondary organic aerosol formation, Phys. Chem. Chem. Phys., 12, 13975-13982, doi:10.1039/C0CP00200C, 2010.
Chhabra, P. S., Flagan, R. C., and Seinfeld, J. H.: Elemental analysis of chamber organic aerosol using an aerodyne high-resolution aerosol mass spectrometer, Atmos. Chem. Phys., 10, 4111-4131, doi:10.5194/acp-10-4111-2010, 2010.

Ciobanu, V. G., Marcolli, C., Krieger, U. K., Weers, U., and Peter, T.: Liquid-Liquid Phase Separation in Mixed Organic/Inorganic Aerosol Particles, J. Phys. Chem. A, 113, 10966-10978, doi:10.1021/jp905054d, 2009.

DeCarlo, P., Kimmel, J., Trimborn, A., Northway, M., Jayne, J., Aiken, A., Gonin, M., Fuhrer, K., Horvath, T., Docherty, K., Worsnop, D. R., and Jimenez, J. L.: Field-deployable, high-resolution, time-of-flight aerosol mass spectrometer, Anal. Chem., 78, 8281-8289, 2006.

Donahue, N. M., Kroll, J. H., Pandis, S. N., and Robinson, A. L.: A two-dimensional volatility basis set - Part 2: Diagnostics of organic-aerosol evolution, Atmos. Chem. Phys., 12, 615-634, doi:10.5194/acp-12-615-2012, 2012.

Fox, T. and Flory, P.: Second-order transition temperatures and related properties of polystyrene. I. Influence of molecular weight, J. Appl. Phys., 21, 581-591, 1950.

Gao, S., Keywood, M., Ng, N. L., Surratt, J., Varutbangkul, V., Bahreini, R., Flagan, R. C., and Seinfeld, J. H.: Low-MolecularWeight and Oligomeric Components in Secondary Organic Aerosol from the Ozonolysis of Cycloalkenes and $\alpha$-Pinene, J. Phys. Chem. A, 108, 10147-10164, doi:10.1021/jp047466e, 2004.

Hall IV, W. and Johnston, M.: Oligomer content of $\alpha$-pinene secondary organic aerosol, Aerosol Sci. Technol., 45, 37-45, 2011.

Hallquist, M., Wenger, J. C., Baltensperger, U., Rudich, Y., Simpson, D., Claeys, M., Dommen, J., Donahue, N. M., George, C., Goldstein, A. H., Hamilton, J. F., Herrmann, H., Hoffmann, T., Iinuma, Y., Jang, M., Jenkin, M. E., Jimenez, J. L., Kiendler-Scharr, A., Maenhaut, W., McFiggans, G., Mentel, Th. F., Monod, A., Prévôt, A. S. H., Seinfeld, J. H., Surratt, J. D., Szmigielski, R., and Wildt, J.: The formation, properties and impact of secondary organic aerosol: current and emerging issues, Atmos. Chem. Phys., 9, 5155-5236, doi:10.5194/acp-9-51552009, 2009.

Höhne, G., Hemminger, W., and Flammersheim, H.: Differential scanning calorimetry, Springer Verlag, 2003.

IPCC: Changes in Atmospheric Constituents and in Radiative Forcing. In: Climate Change 2007: The Physical Science Basis. Contribution of Working Group I to the Fourth Assessment Report of the Intergovernmental Panel on Climate Change, available at: http://www.ipcc.ch/ipccreports/ar4-wg1.htm, 2007.

Jimenez, J. L., Canagaratna, M. R., Donahue, N. M., Prevot, A. S. H., Zhang, Q., Kroll, J. H., DeCarlo, P. F., Allan, J. D., Coe, H., Ng, N. L., Aiken, A. C., Docherty, K. S., Ulbrich, I. M., Grieshop, A. P., Robinson, A. L., Duplissy, J., Smith, J. D., Wilson, K. R., Lanz, V. A., Hueglin, C., Sun, Y. L., Tian, J., Laaksonen, A., Raatikainen, T., Rautiainen, J., Vaattovaara, P., Ehn, M., Kulmala, M., Tomlinson, J. M., Collins, D. R., Cubison, M. J., E., Dunlea, J., Huffman, J. A., Onasch, T. B., Alfarra, M. R., Williams, P. I., Bower, K., Kondo, Y., Schneider, J., Drewnick, F., Borrmann, S., Weimer, S., Demerjian, K., Salcedo, D., Cottrell, L., Griffin, R., Takami, A., Miyoshi, T., Hatakeyama, S., Shimono, A., Sun, J. Y., Zhang, Y. M., Dzepina, K., Kimmel, J. R., Sueper, D., Jayne, J. T., Herndon, S. C., Trimborn, A. M., Williams, L. R., Wood, E. C., Middlebrook, A. M., Kolb, 
C. E., Baltensperger, U., and Worsnop, D. R.: Evolution of Organic Aerosols in the Atmosphere, Science, 326, 1525-1529, doi:10.1126/science.1180353, 2009.

Kalberer, M., Paulsen, D., Sax, M., Steinbacher, M., Dommen, J., Prevot, A. S. H., Fisseha, R., Weingartner, E., Frankevich, V., Zenobi, R., and Baltensperger, U.: Identification of Polymers as Major Components of Atmospheric Organic Aerosols, Science, 303, 1659-1662, doi:10.1126/science.1092185, 2004.

Kanakidou, M., Seinfeld, J. H., Pandis, S. N., Barnes, I., Dentener, F. J., Facchini, M. C., Van Dingenen, R., Ervens, B., Nenes, A., Nielsen, C. J., Swietlicki, E., Putaud, J. P., Balkanski, Y., Fuzzi, S., Horth, J., Moortgat, G. K., Winterhalter, R., Myhre, C. E. L., Tsigaridis, K., Vignati, E., Stephanou, E. G., and Wilson, J.: Organic aerosol and global climate modelling: a review, Atmos. Chem. Phys., 5, 1053-1123, doi:10.5194/acp-5-1053-2005, 2005.

Kim, Y. P., Pun, B. K.-L., Chan, C. K., Flagan, R. C., and Seinfeld, J. H.: Determination of Water Activity in Ammonium Sulfate and Sulfuric Acid Mixtures Using Levitated Single Particles, Aerosol Sci. Technol., 20, 275-284, doi:10.1080/02786829408959683, 1994.

Kirkby, J., Curtius, J., Almeida, J., Dunne, E., Duplissy, J., Ehrhart, S., Franchin, A., Gagné, S., Ickes, L., Kürten, A., Kupc, A., Metzger, A., Riccobono, F., Rondo, L., Schobesberger, S., Tsagkogeorgas, G., Wimmer, D., Amorim, A., F, B., Breitenlechner, M., David, A., Dommen, J., Downard, A., Ehn, M., Flagan, R., Haider, S., Hansel, A., Hauser, D., Jud, W., Junninen, H., Kreissl, F., Kvashin, A., A., L., Lehtipalo, K., Lima, J., Lovejoy, E., Makhmutov, F., Mathot, S., Mikkilä, J., Minginette, P., Mogo, S., Nieminen, T., Onnela, A., Pereira, P., Petäjä, T., Schnitzhofer, R., Seinfeld, S. P., Sipilä, M., Stozhkov, Y., Stratmann, F., Tome, A., Vanhanen, J., Viisanen, Y., Vrtala, A., Wagner, P., Walther, H., Weingartner, E., Wex, H., Winkler, P., Carslaw, K., Worsnop, D., Baltensberger, U., and Kulmala, M.: Role of sulphuric acid, ammonia and galactic cosmic rays in atmospheric aerosol nucleation, Nature, 476, 429-433, 2011.

Koop, T., Bookhold, J., Shiraiwa, M., and Pöschl, U.: Glass transition and phase state of organic compounds: dependency on molecular properties and implications for secondary organic aerosols in the atmosphere, Phys. Chem. Chem. Phys., 13, 19238-19255, doi:10.1039/C1CP22617G, 2011.

Krieger, U. K., Marcolli, C., and Reid, J. P.: Exploring the complexity of aerosol particle properties and processes using single particle techniques, Chem. Soc. Rev., p. Advance article, doi:10.1039/C2CS35082C, 2012.

Kundu, S., Fisseha, R., Putman, A. L., Rahn, T. A., and Mazzoleni, L. R.: High molecular weight SOA formation during limonene ozonolysis: insights from ultrahigh-resolution FT-ICR mass spectrometry characterization, Atmos. Chem. Phys., 12, 5523-5536, doi:10.5194/acp-12-5523-2012, 2012.

Lambe, A. T., Ahern, A. T., Williams, L. R., Slowik, J. G., Wong, J. P. S., Abbatt, J. P. D., Brune, W. H., Ng, N. L., Wright, J. P., Croasdale, D. R., Worsnop, D. R., Davidovits, P., and Onasch, T. B.: Characterization of aerosol photooxidation flow reactors: heterogeneous oxidation, secondary organic aerosol formation and cloud condensation nuclei activity measurements, Atmos. Meas. Tech., 4, 445-461, doi:10.5194/amt-4-445-2011, 2011a.

Lambe, A. T., Onasch, T. B., Massoli, P., Croasdale, D. R., Wright, J. P., Ahern, A. T., Williams, L. R., Worsnop, D. R., Brune, W. H., and Davidovits, P.: Laboratory studies of the chemical composition and cloud condensation nuclei (CCN) activity of secondary organic aerosol (SOA) and oxidized primary organic aerosol (OPOA), Atmos. Chem. Phys., 11, 8913-8928, doi:10.5194/acp11-8913-2011, 2011b.

Lambe, A. T., Onasch, T. B., Croasdale, D. R., Wright, J. P., Martin, A. T., Franklin, J. P., Massoli, P., Kroll, J. H., Canagaratna, M. R., Brune, W. H., Worsnop, D. R., and Davidovits, P.: Transitions from Functionalization to Fragmentation Reactions of Laboratory Secondary Organic Aerosol (SOA) Generated from the OH Oxidation of Alkane Precursors, Environ. Sci. Technol., 46, 5430-5437, doi:10.1021/es300274t, 2012.

Lance, S., Nenes, A., Medina, J., and Smith, J. N.: Mapping the Operation of the DMT Continuous Flow CCN Counter, Aerosol Science and Technology, 40, 242-254, doi:10.1080/02786820500543290, 2006.

Mao, J., Ren, X., Brune, W. H., Olson, J. R., Crawford, J. H., Fried, A., Huey, L. G., Cohen, R. C., Heikes, B., Singh, H. B., Blake, D. R., Sachse, G. W., Diskin, G. S., Hall, S. R., and Shetter, R. E.: Airborne measurement of $\mathrm{OH}$ reactivity during INTEX-B, Atmos. Chem. Phys., 9, 163-173, doi:10.5194/acp-9-163-2009, 2009.

Marcolli, C. and Krieger, U.: Phase changes during hygroscopic cycles of mixed organic/inorganic model systems of tropospheric aerosols, J. Phys. Chem. A, 110, 1881-1893, 2006.

Massoli, P., Lambe, A., Ahern, A., Williams, L., Ehn, M., Mikkilä, J., Canagaratna, M., Brune, W., Onasch, T., Jayne, J., Petäjä, T., Kulmala, M., A., L., Kolb, C. E., Davidovits, P., and Worsnop, D.: Relationship between aerosol oxidation level and hygroscopic properties of laboratory generated secondary organic aerosol (SOA) particles, Geophys. Res. Lett, 37, L24801, doi:10.1029/2010GL045258, 2010.

Mikhailov, E., Vlasenko, S., Martin, S. T., Koop, T., and Pöschl, U.: Amorphous and crystalline aerosol particles interacting with water vapor: conceptual framework and experimental evidence for restructuring, phase transitions and kinetic limitations, Atmos. Chem. Phys., 9, 9491-9522, doi:10.5194/acp-9-9491-2009, 2009.

Murray, B., Wilson, T., Dobbie, S., Cui, Z., Al-Jumur, S., Möhler, O., Schnaiter, M., Wagner, R., Benz, S., Niemand, M., et al.: Heterogeneous nucleation of ice particles on glassy aerosols under cirrus conditions, Nature Geosci., 3, 233-237, 2010.

Murray, B. J.: Inhibition of ice crystallisation in highly viscous aqueous organic acid droplets, Atmos. Chem. Phys., 8, 54235433, doi:10.5194/acp-8-5423-2008, 2008.

Ng, N. L., Canagaratna, M. R., Zhang, Q., Jimenez, J. L., Tian, J., Ulbrich, I. M., Kroll, J. H., Docherty, K. S., Chhabra, P. S., Bahreini, R., Murphy, S. M., Seinfeld, J. H., Hildebrandt, L., Donahue, N. M., DeCarlo, P. F., Lanz, V. A., Prévôt, A. S. H., Dinar, E., Rudich, Y., and Worsnop, D. R.: Organic aerosol components observed in Northern Hemispheric datasets from Aerosol Mass Spectrometry, Atmos. Chem. Phys., 10, 46254641, doi:10.5194/acp-10-4625-2010, 2010.

Nielsen, L. E.: Cross-Linking-Effect on Physical Properties of Polymers, Journal of Macromolecular Science, Part C: Polymer Reviews, 3, 69-103, doi:10.1080/15583726908545897, 1969.

Pankow, J.: An absorption model of the gas/aerosol partitioning involved in the formation of secondary organic aerosol, Atmos. Environ., 28, 189-193, doi:10.1016/1352-2310(94)90094-9, 1994. 
Pedernera, D. A.: Glass formation in upper tropospheric aerosol particles, Ph.D. thesis, Bielefeld University, http://pub. uni-bielefeld.de/publication/2303351, 2008 (in German).

Perraud, V., Bruns, E. A., Ezell, M. J., Johnson, S. N., Yu, Y., Alexander, M. L., Zelenyuk, A., Imre, D., Chang, W. L., Dabdub, D., Pankow, J. F., and Finlayson-Pitts, B. J.: Nonequilibrium atmospheric secondary organic aerosol formation and growth, P. Natl. Acad. Sci., 109, 2836-2841, doi:10.1073/pnas.1119909109, 2012.

Petters, M. D. and Kreidenweis, S. M.: A single parameter representation of hygroscopic growth and cloud condensation nucleus activity, Atmos. Chem. Phys., 7, 1961-1971, doi:10.5194/acp-71961-2007, 2007.

Pfrang, C., Shiraiwa, M., and Pöschl, U.: Chemical ageing and transformation of diffusivity in semi-solid multi-component organic aerosol particles, Atmos. Chem. Phys., 11, 7343-7354, doi:10.5194/acp-11-7343-2011, 2011.

Prenni, A., Petters, M., Kreidenweis, S., DeMott, P., and Ziemann, P.: Cloud droplet activation of secondary organic aerosol, J. Geophys. Res., 112, D10223, doi:10.1029/2006JD007963, 2007.

Renbaum, L. H. and Smith, G. D.: Artifacts in measuring aerosol uptake kinetics: the roles of time, concentration and adsorption, Atmos. Chem. Phys., 11, 6881-6893, doi:10.5194/acp-11-68812011, 2011.

Rietsch, F., Daveloose, D., and Froelich, D.: Glass transition temperature of ideal polymeric networks, Polymer, 17, 859-863, doi:10.1016/0032-3861(76)90251-2, 1976.

Roberts, G. and Nenes, A.: A continuous-flow streamwise thermalgradient CCN chamber for atmospheric measurements, Aerosol Sci. Technol., 39, 206-221, 2005.

Saukko, E., Kuuluvainen, H., and Virtanen, A.: A method to resolve the phase state of aerosol particles, Atmos. Meas. Tech., 5, 259265, doi:10.5194/amt-5-259-2012, 2012.

Seinfeld, J. and Pandis, S.: Atmospheric chemistry and physics: from air pollution to climate change, Wiley New York, 2nd edn., 1998.

Shiraiwa, M., Ammann, M., Koop, T., and Pöschl, U.: Gas uptake and chemical aging of semisolid organic aerosol particles, Proceedings of the National Academy of Sciences, 108, 1100311008, doi:10.1073/pnas.1103045108, 2011.

Sipilä, M., Berndt, T., Petäjä, T., Brus, D., Vanhanen, J., Stratmann, F., Patokoski, J., Mauldin, R. L., Hyvärinen, A.P., Lihavainen, H., and Kulmala, M.: The Role of Sulfuric Acid in Atmospheric Nucleation, Science, 327, 1243-1246, doi:10.1126/science.1180315, 2010.

Song, M., Marcolli, C., Krieger, U. K., Zuend, A., and Peter, T.: Liquid-liquid phase separation and morphology of internally mixed dicarboxylic acids/ammonium sulfate/water particles, Atmos. Chem. Phys., 12, 2691-2712, doi:10.5194/acp-12-26912012, 2012.
Tolocka, M. P., Jang, M., Ginter, J. M., Cox, F. J., Kamens, R. M., and Johnston, M. V.: Formation of Oligomers in Secondary Organic Aerosol, Environ. Sci. Technol., 38, 1428-1434, doi:10.1021/es035030r, 2004.

Vaden, T. D., Imre, D., Beránek, J., Shrivastava, M., and Zelenyuk, A.: Evaporation kinetics and phase of laboratory and ambient secondary organic aerosol, P. Natl. Acad. Sci., 108, 2190-2195, doi:10.1073/pnas.1013391108, 2011.

Varutbangkul, V., Brechtel, F. J., Bahreini, R., Ng, N. L., Keywood, M. D., Kroll, J. H., Flagan, R. C., Seinfeld, J. H., Lee, A., and Goldstein, A. H.: Hygroscopicity of secondary organic aerosols formed by oxidation of cycloalkenes, monoterpenes, sesquiterpenes, and related compounds, Atmos. Chem. Phys., 6, 23672388, doi:10.5194/acp-6-2367-2006, 2006.

Virtanen, A., Joutsensaari, J., Koop, T., Kannosto, J., Yli-Pirilä, P., Leskinen, J., Mäkelä, J., Holopainen, J., Pöschl, U., Kulmala, M., Worsnop, D. R., and Laaksonen, A.: An amorphous solid state of biogenic secondary organic aerosol particles, Nature, 467, 824827, 2010.

Virtanen, A., Kannosto, J., Kuuluvainen, H., Arffman, A., Joutsensaari, J., Saukko, E., Hao, L., Yli-Pirilä, P., Tiitta, P., Holopainen, J. K., Keskinen, J., Worsnop, D. R., Smith, J. N., and Laaksonen, A.: Bounce behavior of freshly nucleated biogenic secondary organic aerosol particles, Atmos. Chem. Phys., 11, 8759-8766, doi:10.5194/acp-11-8759-2011, 2011.

Zahardis, J. and Petrucci, G. A.: The oleic acid-ozone heterogeneous reaction system: products, kinetics, secondary chemistry, and atmospheric implications of a model system - a review, Atmos. Chem. Phys., 7, 1237-1274, doi:10.5194/acp-7-1237-2007, 2007.

Ziemann, P.: Atmospheric Chemistry: Phase matters for aerosols, Nature, 467, 797-798, 2010.

Zobrist, B., Marcolli, C., Pedernera, D. A., and Koop, T.: Do atmospheric aerosols form glasses?, Atmos. Chem. Phys., 8, 52215244, doi:10.5194/acp-8-5221-2008, 2008.

Zobrist, B., Soonsin, V., Luo, B. P., Krieger, U. K., Marcolli, C., Peter, T., and Koop, T.: Ultra-slow water diffusion in aqueous sucrose glasses, Phys. Chem. Chem. Phys., 13, 3514-3526, doi:10.1039/C0CP01273D, 2011.

Zuend, A. and Seinfeld, J. H.: Modeling the gas-particle partitioning of secondary organic aerosol: the importance of liquidliquid phase separation, Atmos. Chem. Phys., 12, 3857-3882, doi:10.5194/acp-12-3857-2012, 2012. 